\title{
The Role, Problems and Countermeasures in the Construction of Experimental Practice Base in the Cultivation of Innovative Talents
}

\author{
Zhenbo Bao ${ }^{1, a^{*}}$, Dengchao Jin ${ }^{1, b}$, Hongjun Teng ${ }^{1, c}$, \\ Yuan Liu ${ }^{1, d}$ and Jinxing Peng ${ }^{1, e}$ \\ ${ }^{1}$ Engineering and Technology College, Tianjin Agricultural University, Tianjin, China, 300384 \\ a*zhenbobao@sohu.com, bjindengchao@163.com, chongjun-teng@163.com, 'lliuyuan@163.com, \\ pengjinxing@163.com
}

Keywords: Innovation and entrepreneurship; Experimental practice; Construction problems; Improve countermeasures

\begin{abstract}
Public entrepreneurship, innovation" is the Chinese government to promote, to encourage individuals and enterprises to venture innovation, college students is an important force in innovation and entrepreneurship. Colleges and universities are an important base for the cultivation of innovative and entrepreneurial talents, which plays an irreplaceable role in the quantity and quality of innovation and entrepreneurship. On the basis of summarizing the role of experimental practice base, this paper analyzes the problems existing in the construction of experimental practice base. Finally, it summarizes the measures to improve the construction of experimental practice base.
\end{abstract}

\section{Introduction}

"Public entrepreneurship, innovation" encourage individuals and enterprises to venture innovation. Promote "public entrepreneurship, innovation", both to expand employment, increase the income of residents. The key factors of "Public entrepreneurship, innovation" is talent, college students are an important force in innovation and entrepreneurship. Colleges and universities are an important base for the cultivation of innovative and entrepreneurial talents, which plays an irreplaceable role in the quantity and quality of innovation and entrepreneurship. School-enterprise cooperation is one of the educational models for cultivating innovative and entrepreneurial talents in colleges and universities; the construction of experimental practice base is the important material conditions in the mode of cooperation between schools and enterprises. As an important carrier of cultivating students' practical ability and innovation ability, the experimental practice base plays an important role in cultivating innovative entrepreneurship. How to build a practical teaching base, to better serve the application of personnel training, has become a general concern of colleges and universities, concerned about the important issue [1-3].

\section{The Role of Experimental Practice Base}

Achieving the sharing of school-enterprise resources and promoting the development of universities and enterprises. Experimental practice base organically connects teaching and production practice, the resources of experimental practice base can make up for the lack of teaching resources; combined with the professional subject knowledge system structure, teachers can project new technology, new results, actual combat experience into the teaching system, and optimize the quality of teaching in colleges and universities. Enterprises can use the technology and achievements of university teachers, and improve the technological content of enterprise products [2-4].

Enhance teachers' ability of innovation and entrepreneurship education. To carry out innovative entrepreneurship education requires teachers not only to have a solid professional theoretical knowledge, but also requires a wealth of practical experience. The use of experimental practice base will enrich the teacher innovation and entrepreneurship experience, and enhance the ability of teachers' research business. The experimental practice base is conducive to teachers to play the comprehensive advantages of colleges and universities, promote the transformation of scientific 
and technological achievements, and improve teachers' ability of innovation and entrepreneurship education [5-6].

Be conducive to the cultivation of students' innovative entrepreneurial ability. Experimental practice base can strengthen the cooperation between schools and enterprises, and help schools and enterprises to jointly develop and implement personnel training program. Experimental practice base can provide a real production environment for students to participate in practice and exercise opportunities, and help students develop innovative entrepreneurial ability to stimulate students' entrepreneurial passion and potential, and to improve market competitiveness and ability to serve the community [6-7].

Be conducive to promoting the establishment of innovative talents training new mechanism. Experimental practice base to promote the diversification of teaching models, change the traditional classroom teaching model, and strengthen scientific research practice education. The establishment of a new talent training mechanism based on innovation and entrepreneurship education is conducive to promote the joint training mechanism between universities and enterprises, and to promote the close connection between talent training and economic development, entrepreneurship and employment needs [5-7].

\section{The Problems in the Construction of Experimental Practice Base}

Experimental practice base long-term mechanism is imperfect. Experimental practice base is mostly teachers, short-term cooperation, failed to form a long-term stable cooperation pattern of scientific research team. The poor stability and sustainable development of the practice teaching base, can not effectively guarantee the practice base for the stability and efficiency of the school practice teaching services [1-3].

Colleges and universities ignore the interests of enterprises seeking, and dampen the enthusiasm of enterprises. In the construction of experimental practice base, colleges and universities do not fully take into account the economic benefits of enterprises, will cause the enterprise human, material and production costs increase; in addition, the university's talents, scientific research, technology and other advantages can not be effectively transformed into the real needs of local enterprises, and dampen the enthusiasm of the enterprise construction experimental practice base [4-5].

Enterprises lack the responsibility of social service, and the enterprise's enthusiasm for experimental practice base construction is not high. Enterprises more themselves as the main body of the economy, while ignoring its social subjects should bear the social responsibility. Based on production safety, management costs and economic benefits, the enthusiasm of enterprises to cultivate innovative entrepreneurial talents is not high $[3,8]$.

The construction policies guarantee system of experimental practice base to be improved. The policy plays a guiding, supporting and coordinating function in promoting the construction of experimental practice base. The government has not enough investment in the construction of the experimental practice base; the tax preferential policies for the enterprises that accept the students' practice are to be implemented, and the rights and obligations in the construction of the experimental practice base are lack of policies and regulations $[3,5,8]$.

The connotation construction of experimental practice base should be improved. During the construction of experimental practice base exists the phenomenon of "attention to quantity, contempt quality", and "attention to the establishment, contempt construction". First of all, college teachers generally high academic qualifications and scientific research ability, but no corporate engineering background, and coupled with heavy teaching tasks, it is difficult to provide effective guidance for students' experimental practice. Second, the practical teaching plan and enterprise production actually is derailed, and the content of experimental practice is poor in compatibility with professional study. Finally, the experimental practice base lacks scientific, fair and objective evaluation index system, and the evaluation mechanism is not perfect $[3,9]$.

The comprehensive benefits of practical teaching base of are relatively low. First of all, the positioning of the experimental practice base is not accurate; the experimental practice base is only 
used for graduation practice, graduation design and other practical links, ignoring the experimental practice base for innovative entrepreneurial talent training role. Secondly, the school-enterprises in the production technology, equipment resources, scientific research and other aspects can not be fully utilized, making the effect of experimental practice base in scientific research, social services and other aspects are not enough, which reduce the experimental practice base comprehensive benefits [2-4].

\section{The Measures to Improve the Construction of Experimental Practice Base}

Strengthen the guidance and guarantee of government policies and systems. Government policy and system play an important role in promoting and safeguarding the construction of experimental practice base, the government should strengthen the guidance, co-ordination and supervision of the practice base. Governments from the local industrial structure develop a reasonable school-enterprise cooperation and development planning, and actively guide schools and enterprises to enhance cooperation. The government should increase the investment of special funds for school and enterprise cooperation; reduce the cost of construction of experimental base. The government should help solve the contradictions and conflicts of interest arising from the construction and operation of the practice base [2-3, 8-9].

Construct a win-win mechanism of school-enterprise and promoting the sustainable development of experimental practice base. The cooperative relations of school-enterprise cooperation is based on the "mutual benefit, complementary advantages, resource sharing", it is the key to the sustainable development of experimental practice base to coordinate the interest relationship of school-enterprises. Colleges and universities should incorporate their corporate interests into the planning of experimental practice teaching, and can effectively support the R\&D of products needed for the development of enterprises. Enterprises should have the social responsibility to serve education, benefit society and focus on education [2-6].

Promote the connotation construction of practical teaching base. The establishment of entrepreneurial education system, the professional education and entrepreneurship education combined, and the experimental practice content and enterprise product design and manufacturing combined. Strengthen the experimental practice instructor team building; hire the enterprise technical personnel as the practice instructor; encourage college teachers to actively participate in the practice of experimental internship; establish an evaluation system to guide students' practice and teaching effect. The process management of practice teaching should be strengthened, and the practice should be guided, assessed, evaluated and recorded $[3,8]$.

Actively promote the cooperation of school-enterprises and improve the comprehensive benefits of experimental practice bases. Take the experimental practice base construction as an opportunity to strengthen the professional setting and industrial development integration. Guide enterprises to participate in the setting of college talents training program, so as to meet the target of personnel training and the employment standard of enterprises. Take the experimental practice base as an opportunity to promote the sharing of resources and advantages of universities and local enterprises in the fields of talents, technology, equipment and scientific research platforms, to promote the comprehensive benefits of the experimental practice base $[3,7,9]$.

\section{Summary}

The construction and use of experimental practice base plays an important practical role in the cultivation of innovative and entrepreneurial talents. Colleges and universities deepen the teaching reform, increase the exchange of scientific and technological achievements of school and enterprise cooperation, and mobilize the enthusiasm of enterprises to participate in school-enterprise cooperation. The experimental practice base can be used as an important base for talent cultivation and an important platform for scientific research to improve the important positions of the local economic development. Enterprises should actively participate in the construction of experimental practice base, and realize the potential benefits of human resources and product technology 
development brought by the experimental practice base. The government should exert its guidance and service function to guarantee the construction policy of experimental practice base. In conclusion, the experimental practice base plays an important role in the cultivation of innovative entrepreneurial talents, and the construction of experimental practice base is a complicated process which requires the joint efforts of universities, enterprises and governments [6-7].

\section{Acknowledgements}

This work was sponsored by Tianjin Agricultural University Teachers Education Reform and Innovation to Guide the Development of the Project No. 20170904 and Tianjin Agricultural University Education and Teaching Reform Project No. 2016-B-17.

\section{References}

[1] R. Tong: Higher Education of Sciences, (2017) No.2, p.26-33.

[2] Z.G. Wang, Z.G. Wang, Y. Zang, Y.H. Jiao and P. Jiao: JOURNAL OF HUBEI POLYTECHNIC UNIVERSITY, Vol. 33 (2017) No.3, p.69-72.

[3] Q.H. Xu: Experimental Technology and Management, Vol. 34 (2017) No.1, p.232-234+239.

[4] G.H. Huang: JOURNAL OF MINNAN NORMAL UNIVERSITY, Vol. 30 (2016) No.3, p.150 -152 .

[5] G.H. Cheng, C.M. Liu and J.L. Bei: Journal of Huaihai Institute of TechnologyCHumanities

[6] (Social Sciences Edition), Vol.14 (2016) No.2, p.135-137.

[7] G.P. Xiao: CHINESE UNIVERSITY SCIENCE \& TECHNOLOGY, (2017) No.7, p.84-87.

[8] Y.F. Zeng: Journal of Jingdezhen University, Vol. 32 (2017) No.2, p.89-93.

[9] F. Peng: Journal of Higher Education, (2016) No.3, p.25-27.

[10] Y. Cai: Journal of Shandong Institute of Commerce and Technology, Vol.16 (2016) No.4, p.63-66. 